\title{
Different strategies used in the retention phase of orthodontic treatment
}

Vinicius Schau de Araújo Lima', Felipe de Assis Ribeiro Carvalho², Rhita Cristina Cunha Almeida², Jonas Capelli Júnior ${ }^{3}$

Objective: To identify most frequent clinical conducts, considering the following variables: 1) used appliances; 2) time of use; 3) protocol of use in daily hours and evolution with along time; 4) percentage of patients in follow up 1 year after treatment; and 5) most frequent observed relapses..

Methods: It was used a questionnaire distributed to all specialization course of Orthodontics inscribed in the Brazilian Federal Council of Dentistry until October of 2005.

Results and Conclusion: It was obtained 91 valid questionnaires. For data analysis were used descriptive statistics and chi-square for linear tendency and chi-square for linear trend and chi-square for multivariate linear trend. We can conclude that: 1) on upper arch, the most used appliances were Hawley, wraparound and acetate plate; in the lower multi-stranded rod, steel rod not bonded to incisors and rod bonded to the incisors; 2) it was indicated its use for more than 24 months for the upper arch, with a trend toward its less use than in the lower arch; 3) the protocol of use in the upper arch begins with 24 hours/day, reducing after the second year; for the lower arch the protocol of hours/day was kept stable; 4 ) after 1 year of retention most than $50 \%$ of treated cases were re-examined; 5) most common relapses were crowding, giroversion and opening of diastemas.

Keywords: Retention. Relapse. Stability.

${ }^{1}$ Specialist in Orthodontics, UERJ.

${ }^{2} \mathrm{PhD}$ in Orthodontics, UERJ.

${ }^{3} \mathrm{PhD}$ in Orthodontics. Associate Professor of Orthodontics, UERJ.

\author{
How to cite this article: Lima VSA, Carvalho FAR, Almeida RCC, Capelli Júnior \\ J. Different strategies used in the retention phase of orthodontic treatment. Dental \\ Press J Orthod. 2012 July-Aug;17(4):115-21. \\ Submitted: September 22, 2008 - Revised and accepted: November 24, 2008 \\ " The authors report no commercial, proprietary or financial interest in the products \\ or companies described in this article. \\ Contact address: Felipe de Assis Ribeiro Carvalho \\ Av. das Américas, 3434 - Bloco 05 - sala 223, Barra da Tijuca \\ Rio de Janeiro/RJ - Brazil - CEP: 22.640-102 - E-mail: carvalhofar@gmail.com
}




\section{Diferentes estratégias utilizadas na fase de contenção do tratamento ortodôntico}

Vinicius Schau de Araújo Lima', Felipe de Assis Ribeiro Carvalho², Rhita Cristina Cunha Almeida², Jonas Capelli Júnior ${ }^{3}$

Objetivo: identificar as condutas clínicas mais utilizadas, considerando-se as seguintes variáveis: 1) aparelhos utilizados; 2) período de utilização; 3) protocolo de utilização, em horas diárias, e sua evolução com o passar dos meses; 4) percentual de pacientes controlados 1 ano pós-tratamento; e 5) as recidivas mais frequentemente observadas.

Métodos: utilizou-se um questionário distribuído para todos os cursos de Especialização em Ortodontia cadastrados no CFO até outubro de 2005.

Resultados e Conclusão: foram obtidos 91 questionários válidos. Para a análise dos dados, utilizou-se estatística descritiva e os testes qui-quadrado para tendência linear e qui-quadrado para tendência linear multivariado. Concluiu-se que: 1) na arcada superior, os aparelhos mais utilizados foram o aparelho de Hawley, o wraparound e a placa de acetato; já na inferior, barra de fio multifilamentado, barra de aço sem colagem em incisivos e barra com colagem nos incisivos; 2) indicou-se sua utilização por mais de 24 meses para a arcada superior, com uma tendência de menor utilização nessa arcada do que na inferior; 3) o protocolo de utilização na arcada superior inicia-se com 24 horas/dia, reduzindo-se após o segundo ano; para a arcada inferior, o protocolo em horas/dia foi estável; 4) após um ano de contenção, foram reexaminados mais de $50 \%$ dos casos tratados; 5) as recidivas mais comuns foram apinhamento inferior, giroversões e reabertura de diastemas.

Palavras-chave: Contenção. Recidiva. Estabilidade.

${ }^{1}$ Especialista em Ortodontia, UERJ.

${ }^{2}$ Doutores em Odontologia, Universidade do Estado do Rio de Janeiro (UERJ).

${ }^{3}$ Doutor e Livre Docente em Ortodontia. Professor Associado da disciplina de Ortodontia da Faculdade de Odontologia da UERJ.

\footnotetext{
Como citar este artigo: Lima VSA, Carvalho FAR, Almeida RCC, Capelli Júnior J. Different strategies used in the retention phase of orthodontic treatment. Dental Press J Orthod. 2012 July-Aug;17(4):115-21.

Enviado em: 22 de setembro de 2008 - Revisado e aceito: 24 de novembro de 2008

» Os autores declaram não ter interesses associativos, comerciais, de propriedade ou financeiros que representem conflito de interesse nos produtos e companhias descritos nesse artigo.

Endereço para correspondência: Felipe de Assis Ribeiro Carvalho Av. das Américas, 3434 - bloco 05 - sala 223, Barra da Tijuca - Rio de Janeiro/RJ CEP: 22.640-102 - E-mail: carvalhofar@gmail.com
} 


\section{INTRODUCTION}

The retention stage of orthodontic treatment is fairly discussed in the literature and despite all attention deposited in this area, it still is the most difficult stage of orthodontic treatment.

The misunderstanding around undesirable movements that occur in the teeth, as for example, the effects of residual growth, periodontal problems, different occlusal forces and even the controversial role of third molars in the etiology of late crowding of the lower anterior region contribute complicating the management of this stage. ${ }^{16,17}$

Case, Angle and Hawley, reputed personalities in the history of Orthodontics, had already spoken about the orthodontic retention paying attention to professional negligence. ${ }^{4}$

It is difficult to estimate with precision the total hours indicated for patients and for how long they should use retainers, in other words, we are still searching for a protocol to make retention stage more adequate for every case.

\section{LITERATURE REVIEW}

Retention is the stage of orthodontic treatment that consists of maintaining the correct position of the teeth after moving them. ${ }^{11}$

According to Case $^{4}$ the art of retention will never be as accurate as the science of tooth correction, having little or no control regarding natural influences on teeth.

The main factors related to failure of orthodontic retention are: Hereditary influences; Disrespect to biological limits of dental movement and the use of an inappropriate retention system among others. ${ }^{3,8,10,11,12}$

Clinical experience has shown over the years that retention is achieved with the use of removable and fixed retainers. A fixed appliance for lingual retention, a Hawley removable appliance, as well as the thermoplastic retainer are commonly used..$^{17}$

The thermoplastic retainer was described in 1971 by Ponitz, and consists of a thermoplastic polymer, heated in a vacuum inclusor in such a way that it suits the model of the arch which will be retained. This appliance is durable, esthetic, easy to clean, presents low cost when compared to steel wire with acrylic and require few adjustments after the laboratory manufacture. ${ }^{7}$

The Hawley appliance is one of the most commonly used. It was developed in the 1920's as an active removable appliance. It is composed of retention clips on the molars and a canine to canine buccal arch, with loops for adjustment, embedded in an acrylic palatal portion. The "wraparound" type orthodontic clip is similar to the Hawley, however the buccal arch extends over all upper teeth not needing additional retention clips. ${ }^{13}$

Sauget et $\mathrm{a}^{15}$ observed the appearance of new contacts points in the occlusion in the retention stage, which would be positive accommodation for the orthodontic treatment. The study compared the Hawley appliance and acetate appliance covering all elements. The Hawley retainer showed a greater number of contact points, but it was not analyzed if these contact points are solid benefits to the occlusion of the patient.

The canine to canine retention in the mandibular arch is often used, employing smooth steel or multifilament wires, bonded only on canines or all elements. This type of retention does not require cooperation, however requires adequate maintenance and hygiene. ${ }^{1.8}$

Canine to canine fixed retainers maintain alignment after orthodontic treatment. However, a $20 \%$ failure rate can be expected after 3 years and no evidence of damage to hard or soft tissue adjacent to the wire can be noticed. ${ }^{2}$

There is not a known usage time for using retention, it is only known that at least 232 days are necessary for periodontal fibers to reorganize into the new position. ${ }^{5}$ Even if the dental elements are stabilized throughout the period of reorganization of the periodontal fibers, in the long term some relapse will occur. There is no agreement in the literature concerning the duration of the retention period. Some authors defend periods of two to three weeks, even occurring indication of permanent retention., ${ }^{8,11}$

The biggest challenge for the dental stabilization occurs after rotation correction. ${ }^{5,6,18}$ Studies in dogs, performed by Reitan ${ }^{14}$ histologically demonstrated the persistence of distention of connective tissue fibers in the periodontium of the supracrestal area seven months after the induction of rotation movement.

Edwards ${ }^{5}$ produced a simple surgical procedure that alleviated the influence of periodontal fibers that used to rotate the dental element. Campbell, Moore and Mathews named this intervention as circumferential supracrestal fibrotomia. ${ }^{6}$ 


\section{OBJECTIVE}

To identify clinical procedures used by Orthodontists associated to specialist training centres throughout the national territory, for the following variables:

1) Appliances mostly used for the upper and lower arches.

2) Time interval, in months, using the system.

3) Protocol for use, in hours, of retention over the months

4) Percentage of patients monitored by Orthodontists 1 year after the end of active treatment.

5) Most frequently observed relapses.

\section{MATERIAL AND METHODS}

A descriptive survey was made whose universe was composed of teachers of specialization courses in Orthodontics and Facial Orthopedics that were accredited and recognized by the Federal Dental Council until October 2005. The listing for these courses was

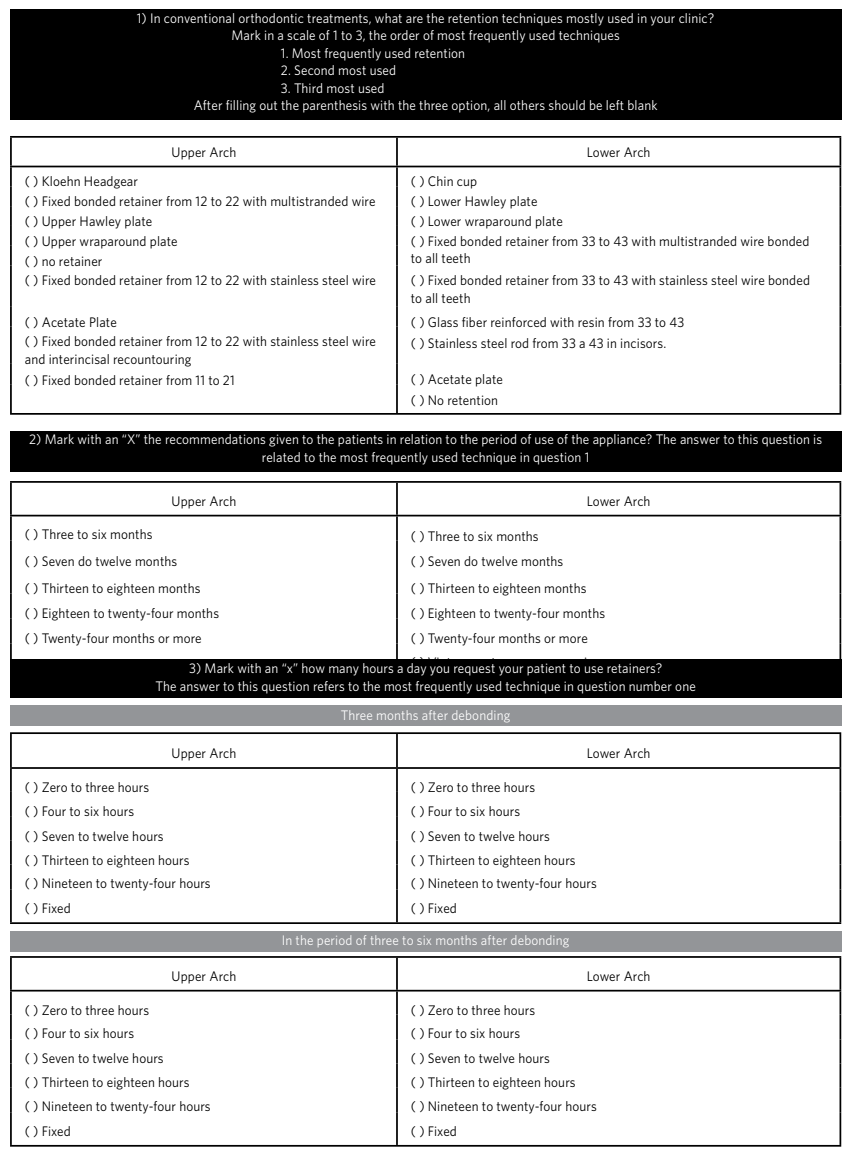

Figure 1 - The final questionnaire sent to the selected graduate courses. obtained in the catalog of the Brazilian Association of Orthodontist of 2005 and, by e-mail, collected directly from the Federal Dental Council, there was no other criteria for this selection.

A questionnaire was devised and was validated in compliance with formatting and wording rules advocated by Willians, ${ }^{19}$ where a simple, clear language vocabulary (avoiding jargon and regional terms), short questions, clear and objective, avoiding phrases with more than 20 words is indicated. This "pilot" questionnaire was distributed to faculty and doctoral students of the institution which coordinated this study, suggested changes were made until everyone involved in the preliminary assessment did not present difficulties in answering the questions in a simple way.

The final questionnaire was sent to all selected courses $(n=226)$, with an attached letter describing the purpose of this study (Fig 1).

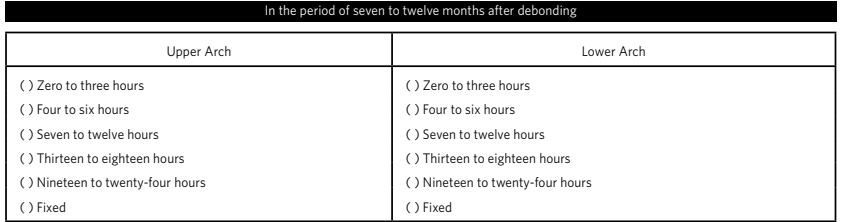

\begin{tabular}{|l|l|}
\hline \multicolumn{1}{|c|}{ In the period of thirteen to eighteen months affer debonding } \\
\hline \multicolumn{1}{|c|}{ Upper Arch } & \multicolumn{1}{|c|}{ Lower Arch } \\
\hline () Zero to three hours & () Zero to three hours \\
() Four to six hours & () Four to six hours \\
() Seven to twelve hours & () Seven to twelve hours \\
() Thirteen to eighteen hours & () Thirteen to eighteen hours \\
() Nineteen to twenty-four hours & () Nineteen to twenty-four hours \\
() Fixed & () Fixed \\
\hline
\end{tabular}
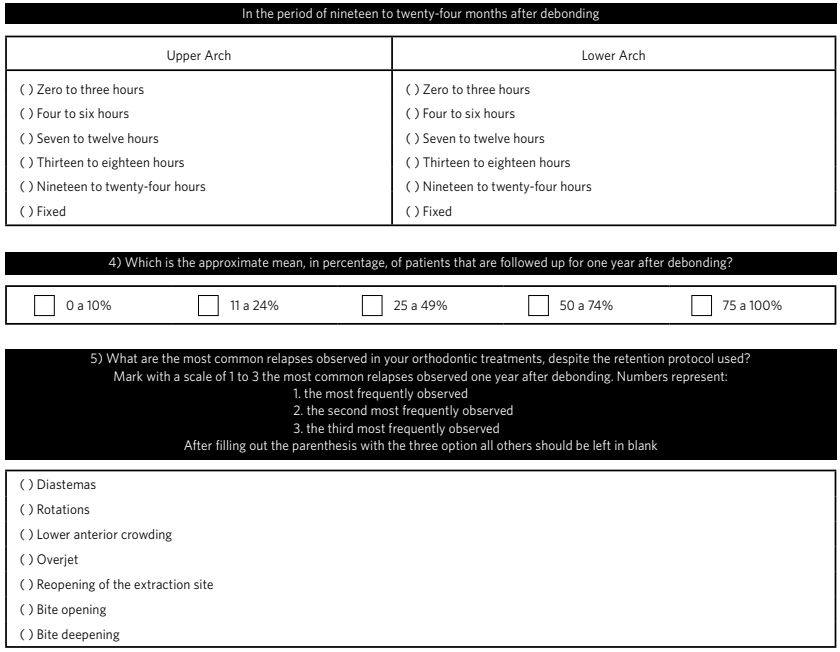


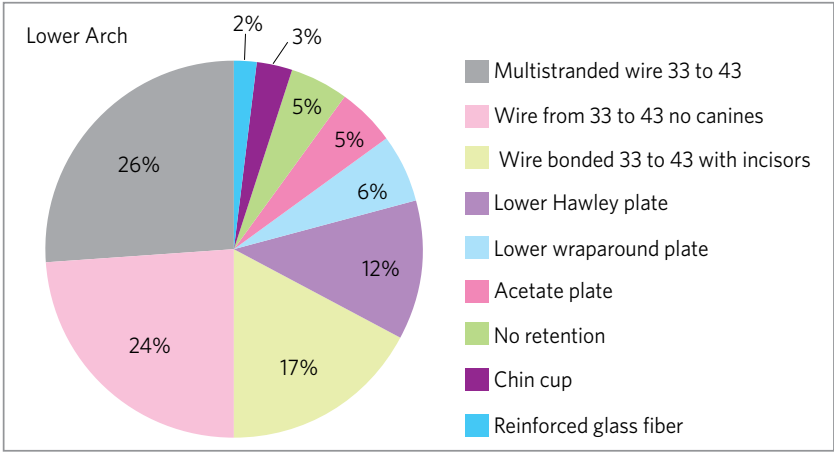

Figure 2 - Main retention techniques used after orthodontic treatment in the lower $\operatorname{arch}(n=91)$.

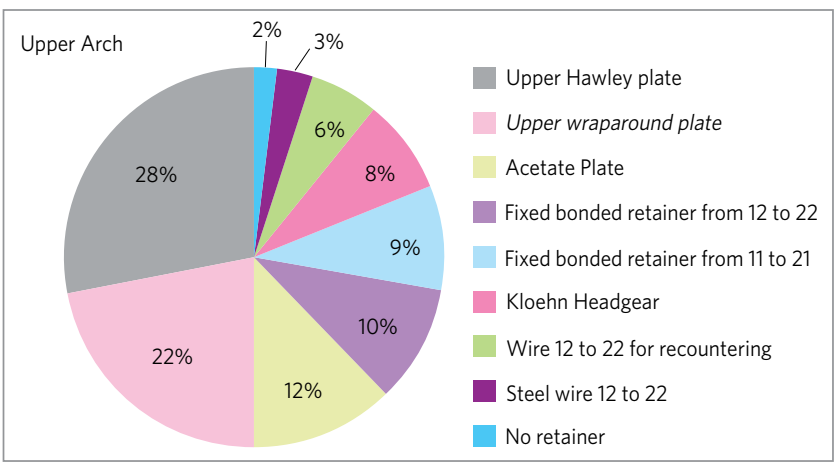

Figure 3 - Main techniques of retention used after orthodontic treatment in the upper $\operatorname{arch}(n=91)$.

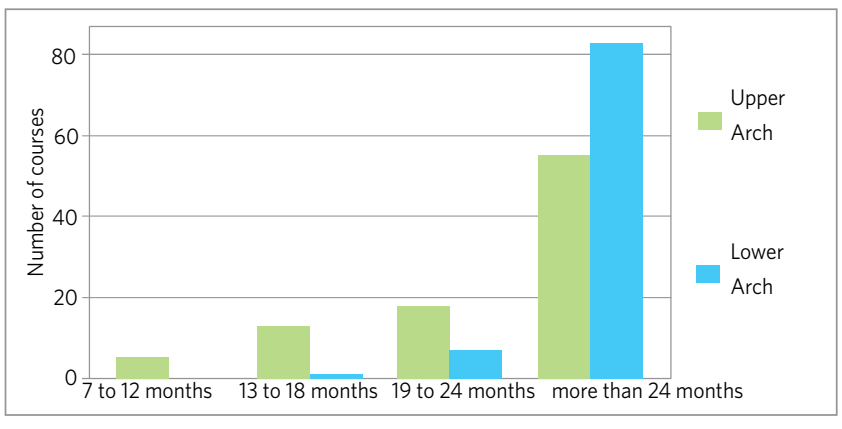

Figure 4 - Period of use of the retainer after orthodontic treatment, between the number of courses $(n=91)$.

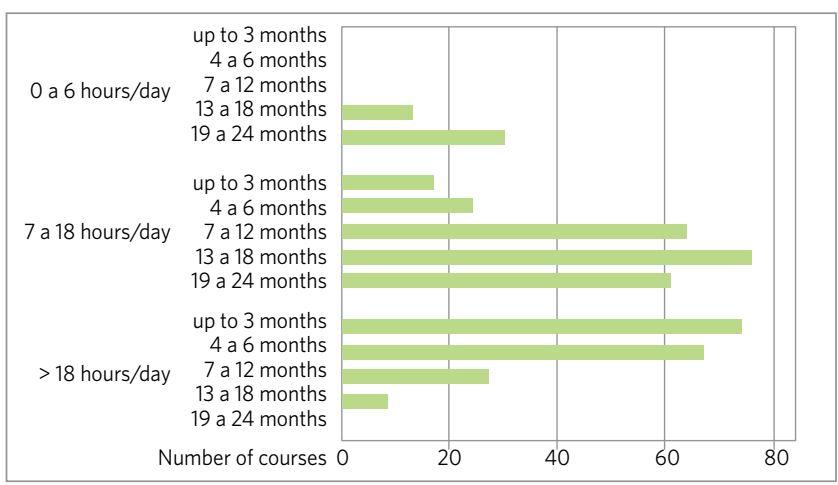

Figure 5 - Hours of daily use of retainer in relation to time (in months) after debonding in the upper arch. Number of courses.

\section{Statistical analysis}

The chi-squared test was used for linear trend and multivariate linear trend.

\section{RESULTS}

Of the total of the institutions ( $\mathrm{n}=226)$, only 183 could be contacted. One hundred and five questionnaires were collected, and of these 23 were returned due to filling in doubts and/or erasures. After these were answered again 14 questionnaires were still with errors and/or deletions, being then excluded, thus 91 valid questionnaires were obtained.

Evaluating if the period of retention use in months, a growing linear trend was observed, evaluated by chisquared test for linear trend $(\mathrm{p}<0.69)$.

It was observed in Figure 4, a trend for later removal of lower retention when compared to upper.

In Figure 5 the number of hours per day of retention appliance use in relation to the number of months after treatment was correlated. There was a linear trend for both variables $(\mathrm{p}<0.00)$, demonstrating a decrease in the amount of daily hours of appliance use as time of removal increased

By comparison with the chi-squared test for linear tendency, there was a tendency to maintain the lower arch retainer for over 24 months $(\mathrm{p}<0.33)$ (Fig 6).

When the amount of followed up patients was evaluated, a tendency for return of the majority of patients was observed (Fig 7).

Finally, considering the answers referring to the main relapses observed during retention period, the most commonly observed was the lower anterior crowding, with approximately $34 \%$ (Fig 8).

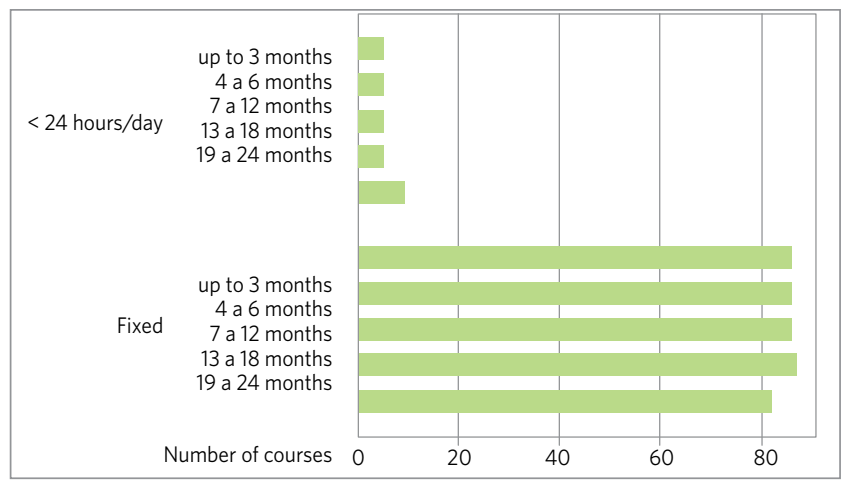

Figure 6 - Hours of daily use of retainer in relation to time (in months) after debonding in the lower arch. 


\section{DISCUSSION}

Littlewood et $\mathrm{al}^{11}$ formulated a systematic review to evaluate the effectiveness of different strategies of retention, and concluded that it is not possible to fully assess the effectiveness used to stabilize tooth position after corrective treatment, due to the low quality of studies found in the literature. They emphasized the need for further research in order to obtain concrete evidence on the subject. ${ }^{11.11}$

In this study, the questionnaire were directed to a professor of Orthodontics, which according to Willians ${ }^{19}$ would represent a response from the entire group of teachers from the evaluated institution. Ninety-one questionnaires were answered (40.08\%), since for a result to be representative of a universe a return of $80 \%$ of of valid questionnaires is necessary. ${ }^{19}$ However, it is possible to observe in the literature that the percentage of answers in this work was greater than or equal to other researches, such as Kiyak et al ${ }^{9}$ that achieved a $41 \%$ return rate.

The results of this study found that the Hawley and wraparound plates were the most used in the upper arch,followed by the acetate plate. According to Sauget ${ }^{15}$ acrylic apparatus with stainless steel wire are more efficient in retaining tooth extrusion when compared to acetate plate.

Gardner, Dunn and Taloumis ${ }^{7}$ describe the Ponitz plate as esthetical, easy to clean, low cost and requires minimal adjustments for placement. However, the acrylic portions of Hawley and wraparound plates are more resistant than the acetate and the metallic portion allows you to correct small dental irregularities as well as it be transformed into bite plates for stabilization of deep bite correction. ${ }^{4.7}$

Such versatility of acrylic appliances with wires probably justifies its greater use by professionals, even having a higher cost and a more elaborate construction compared to lab acetate plates.

The multistranded wire retainers bonded to upper incisors are well indicated in cases of diastemas and in cases with periodontal problems. This type of retention is discreet and does not require patient cooperation. Multistranded wires appeared as the most widely used option, with $18.3 \%$ (adding if those bonded to two central incisors and also to the lateral incisors) when compared to stainless steel wire, which also added were in $9.2 \%$ of cases.

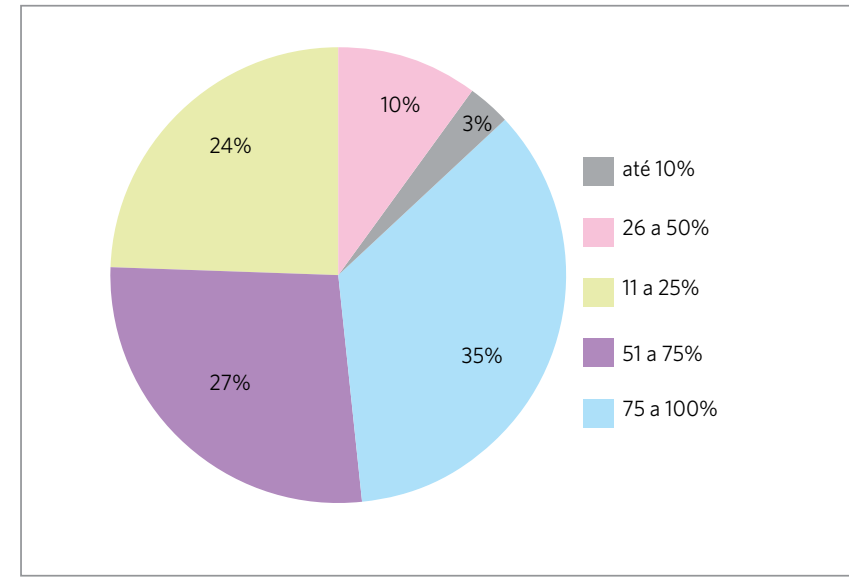

Figure 7 - Rate of patient return after the end of treatment $(n=91)$.

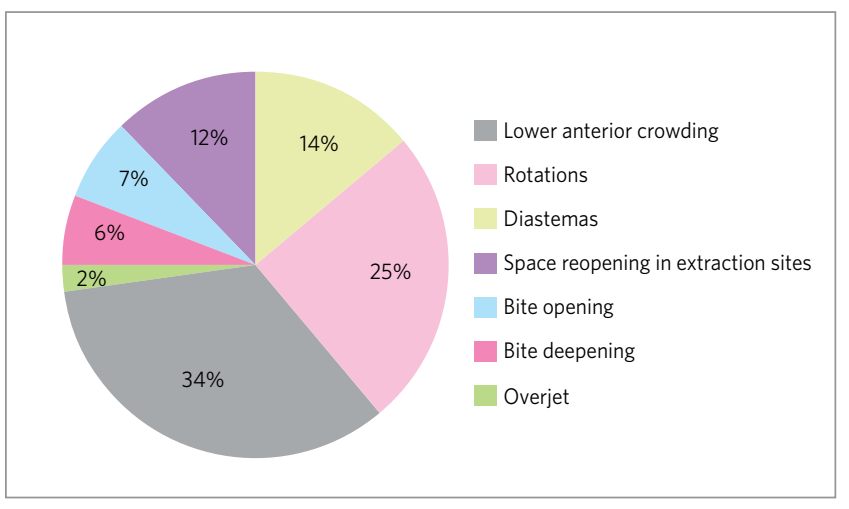

Figure 8 - Major relapse after treatment orthodontic.

It is expected from the multistranded wire to allow a differential movement of the teeth, what is best in cases periodontally committed. ${ }^{17}$

Both multistranded and stainless steel wires can be used concomitantly with other types of retention for the remainder of the arch. Its failure index is $47 \%$ particularly when used in cases of deep bite, so the combination of lingual bonded wires with the Hawley and "wraparound" plates can be a good option to decrease the failure rate..$^{1,11}$

In the lower arch canine to canine bonded retainer showed up as the mostly used in the conditions assessed in this study. This fact is due probably to its fixed character, that justifies its employment in a region where most Orthodontists observe relapses.

The use of the canine to canine fixed retainer with multistranded wire bonded to upper canines and incisors was the most cited, probably because you have better composite adhesion ${ }^{10}$ and by using a wire that 
allows some tooth movement. Artun et al ${ }^{1,2}$ however, proved there is no difference between the use of stainless steel and multistranded wires.

Another point of divergence is the duration of use of retention appliances, both for upper and lower arches

According to Silva Filho, Kubitski and Marinho ${ }^{17}$ the lower retention should be used for long-term or indefinitely. Reitan ${ }^{14}$ in his studies noted that the periodontal fibers remain with memory until 7 months after removal of fixed appliances, which would force the use of appliances, both in the upper and lower arches for 7 months at a minimum for the retention of the fixed orthodontic treatment. The results of this study showed a concern about the use of retention appliances because it was recommended in, $80.2 \%$ of answered questionnaires, with use for a period of 19 or more months after removal of fixed appliances for the upper arch, and there is an even greater concern for the lower arch with $98.7 \%$ of indications for use for more than 19 months.

Considering the number of hours per day that the retention appliance is used for the upper arch there is a tendency to decrease the duration of the use of the appliance over time, that is, over the months the usage hours decreases, showing a linear trend. The decrease in hours of daily use of retention may be related to a lower need for use, contrary to the findings of Reitan ${ }^{14}$ that indicates that the periodontal fibers take 7 months to decrease its effects on orthodontically corrected teeth.

In the lower arch the result of hours used per day presented a trend toward stability, given the continued use by approximately $94 \%$ of the professionals in the first 24 months. This result is in agreement with Silva Filho et al. ${ }^{17}$

After lower anterior crowding, the most commonly seen type of relapse was rotation. The diastemas appeared in third place with $14.3 \%$. The diastemas are retained with fixed retainers, widely used in these cases, bonded wires in diastema sites, previously observed by Orthodontists at the time of diagnosis. The reopening of the extraction spaces is also cause for attention.
In this study, this wasn't as cited by respondents such as the others. This finding may be biased since only part of the cases is treated with extractions, so ideally there should be a questionnaire covering what would take place only in cases with dental extractions. Silva Filho ${ }^{17}$ recognizes this as an important relapse and cites the fixed retainers extended up to pre molars as an option.

Patient control by professionals was examined in order to verify whether the replies obtained were representative of evaluated reality clinic. Of all respondents $62 \%$ reported one year follow up of $51 \%$ or more of the cases. This finding contributes to the reliability of answers analyzed, because the cases dealt with were followed up after one year for most patients.

\section{CONCLUSION}

The present study may conclude that:

1) The most frequently used retainers were in decreasing order for the upper arch: the Hawley plate, the wraparound plate and the acetate plate. In the lower arch: fixed bonded retainer with multistranded wire from canine to canine, fixed retainer with stainless steel bonded only to canines, and stainless steel fixed retainer also bonded to incisors.

2) The recommendation with regard to the use, in months, for the upper arch was 24 months or more, however there is a tendency to be less than the use in the lower arch, that proved to be constant.

3) The protocol for the upper retention use starts normally with 24 hours use, and there is a reduction after the second year to 12 hours daily. For the lower arch the fixed retention was most frequently used, the hours of use was stable, due to impossibility of removal by the patient.

4) After one year of retention Orthodontists examined, over $50 \%$ of treated cases.

5) The most commonly observed relapse were: Lower anterior crowding, rotations and reopening of diastemas, in that order. 


\section{REFERENCES}

1. Artun J, Spadafora AT, Shapiro PA, McNeill RW, Chapko MK. Hygiene status associated with different types of bonded, orthodontic canine-to-canine retainers. A clinical trial. J Clin Periodontol. 1987 Feb;14(2):89-94.

2. Artun J, Spadafora AT, Shapiro PA. A 3-year follow-up study of various types of orthodontic canine-to-canine retainers. Eur J Orthod. 1997 Oct;19(5):501-9.

3. Blake M, Bibby K. Retention and stability: A review of the literature. Am J Orthod Dentofacial Orthop. 1998 Sep;114(3):299-306

4. Case CS. Principles of retention in orthodontia. Am J Orthod Dentofacial Orthop. 2003 Oct;124(4):352-61.

5. Edwards JG. A surgical procedure to eliminate rotational relapse Am J Orthod. 1970 Jan;57(1):35-46.

6. Edwards JG. A long-term prospective evaluation of the circumferential supracrestal fiberotomy in alleviating orthodontic relapse. Am J Orthod Dentofacial Orthop. 1988 May;93(5):380-7.

7. Gardner GD, Dunn WJ, Taloumis L. Wear comparison of thermoplastic materials used for orthodontic retainers. Am J Orthod Dentofacial Orthop. 2003 Sep;124(3):294-7.

8. Kaplan $\mathrm{H}$. The logic of modern retention procedures Am J Orthod Dentofacia Orthop. 1988 Apr;93(4):325-40.

9. Kiyak HA, Persson RE, Persson GR. Influences on the perceptions of and response to periodontal disease among older adults. Periodontol 2000. 1998 Feb;16:34-43.

10. Little RM, Riedel RA, Artun J. An evaluation of changes in mandibular anterior alignment from 10 to 20 years postretention. Am J Orthod Dentofacial Orthop. 1988 May;93(5):423-8.
11. Littlewood SJ, Millett DT, Doubleday B, Bearn DR, Worthington HV. Retention procedures for stabilizing tooth position after treatment with orthodontic braces. Cochrane Database Syst Rev. 2006 Jan 25;(1):CD002283.

12. Melrose C, Millett DT. Toward a perspective on orthodontic retention? Am J Orthod Dentofacial Orthop. 1998 May;113(5):507-14

13. Proffit WR, Fields HW Jr. Contemporary orthodontics. 2nd ed. St. Louis: Mosby, 1993.

14. Reitan K, Kvam E. Comparative behavior of human and animal tissue during experimental tooth movement. Angle Orthod. 1971 Jan;41(1):1-14.

15. Sauget E, Covell DA Jr, Boero RP, Lieber WS. Comparison of occlusal contacts with use of Hawley and Clear Overlay Retainers. Angle Orthod. 1997;67(3):223-30.

16. Shanley LS. The influence of mandibular third molars on mandibular anterior teeth. Am J Orthod. 1962 Oct;48(10):786-7.

17. Silva Filho OG, Kubitski MG, Marinho ET. Contenção fixa inferior $3 \times 3$ : Considerações sobre sua confecção, colagem direta e remoção. Rev Clín Ortod Dental Press. Dez 2004-Jan 2005:3(6):17-24.

18. Taner TU, Haydar B, Kavuklu I, Korkmaz A. Short-term effects of fiberotomy on relapse of anterior crowding. Am J Orthod Dentofacial Orthop. 2000 Dec;118(6):617-23.

19. Williams A. How to write and analyze a questionnaire. J Orthod. 2003 Sep;30(3):245-52. 